Research Article

\title{
Self-Image Congruence, Functional Congruence, and Mobile App Intention to Use
}

\author{
Shuhui Wu, ${ }^{1}$ Minglun Ren, ${ }^{1}$ Abdul Hameed Pitafi, ${ }^{1}$ and Tahir Islam (i) ${ }^{2}$ \\ ${ }^{1}$ School of Management, Hefei University of Technology, Hefei, China \\ ${ }^{2}$ School of Economics and Management, Tongji University, Siping Road 1239, Shanghai 200092, China \\ Correspondence should be addressed to Tahir Islam; kktahir@hotmail.com
}

Received 13 February 2020; Revised 5 July 2020; Accepted 21 November 2020; Published 12 December 2020

Academic Editor: Carlos T. Calafate

Copyright (c) 2020 Shuhui Wu et al. This is an open access article distributed under the Creative Commons Attribution License, which permits unrestricted use, distribution, and reproduction in any medium, provided the original work is properly cited.

Although the research on the technology acceptance model (TAM) has received much attention, limited research has been done on the role of self-image congruence on the mobile application (app) intention to use. Therefore, leveraging the lens of the selfcongruence theory, the primary objective of the present research is to examine the impact of self-image and functional congruence on the mobile app intention to use. We conduct a survey and collect 349 responses from Chinese smartphone users. The results of the current research reveal that self-image congruence is positively significantly related to mobile app intention to use. Also, our findings show that symbolic congruence is a vital determinant of the mobile app intention to use among Chinese smartphone users. Overall, the present study extends the understanding of TAM and concludes that symbolic congruence, such as functional attributes, is equally essential for technology intention to use. Moreover, this study extends the TAM and self-congruence theory literature by empirically investigating and validating the conceptual framework. The present study highlights the significance of self-image congruence to understand the user mobile app adoption behavior better. It provides important knowledge for the app developers, researchers, policymakers, and marketing managers of the famous social commerce and popular brand apps.

\section{Introduction}

"I do not have the intention to use $\mathrm{X}$ mobile application because it is not congruent with my personal and cultural values and might cause embarrassment in my social circle. Such a potential risk of social embarrassment motivates the individual to seriously consider the self-congruity role while using the specific App. Chen et al.[1] claimed that two-thirds out of the millions of Apps in various App stores are seldom downloaded. Hsu et al.[2] demonstrated that Google Play Store held more than 1 million Apps, in which 90\% have been installed less than 50,000 times. "

The information system (IS) literature increasingly exhibits that technology acceptance or evaluation is measured by not only functional factors [3-6] but also symbolic constructs $[7,8]$. Previous research supports the hypothesis that the self-concept often dictates the individuals' decision $[7,9,10]$. Individuals opt for products and services which are symbolically congruent or identical to their self-image
$[11,12]$. Scholars have found that self-image congruence has a direct positive influence on customers' preconsumption evaluation, such as attitude, option to select, and willingness to use $[12,13]$, including postconsumption evaluation such as customer loyalty and brand attachment [7] shown in Table 1. Liang et al. [19] stated that understanding the key determinants of App intention to use is indispensable. Over the last two decades, the extant literature has widely studied the technology acceptance model (TAM) [20-23], unified theory of acceptance and use of technology (UTAUT1 and 2) [24-26], the theory of reasoned action (TRA) [27], and technology fit theory (TTF) [28] and researched various functional factors that influence the technology adoption. However, the published research highlights the effect of social factors with technology adoption $[29,30]$ rather than an individual and psychological association with technology acceptance.

Mobile applications represent a significant and flourishing force in IS and consumer research [31] because an 
TABLE 1: Extant literature on the self-image congruence.

\begin{tabular}{|c|c|c|c|}
\hline Studies & $\begin{array}{c}\text { Independent } \\
\text { variables }\end{array}$ & Dependent variables & Findings \\
\hline Jamal and Goode [14] & $\begin{array}{l}\text { Self-image } \\
\text { congruence }\end{array}$ & Band preference satisfaction & $\begin{array}{c}(+) \\
\text { related } \\
(+) \\
\text { related } \\
(+)\end{array}$ \\
\hline Graeff [15] & $\begin{array}{l}\text { Self-image } \\
\text { congruence }\end{array}$ & $\begin{array}{l}\text { Public consumption } \\
\text { Private consumption }\end{array}$ & $\begin{array}{l}\text { related } \\
(+) \\
\text { related }\end{array}$ \\
\hline $\begin{array}{l}\text { Sirgy [16] and Jamal and Al- } \\
\text { Marri [17] }\end{array}$ & $\begin{array}{l}\text { Self-image } \\
\text { congruence }\end{array}$ & Brand preference on satisfaction & $\begin{array}{l}(+) \\
\text { related } \\
(+)\end{array}$ \\
\hline Sirgy [16] & $\begin{array}{c}\text { Actual self- } \\
\text { congruity } \\
\text { Ideal self-congruity }\end{array}$ & Purchase motivation & $\begin{array}{l}\text { related } \\
(+) \\
\text { related } \\
(+) \\
\text { related } \\
(+) \\
\text { related }\end{array}$ \\
\hline Sirgy et al. [10] & $\begin{array}{l}\text { Self-image } \\
\text { congruence } \\
\text { Functional } \\
\text { congruence }\end{array}$ & Consumer behavior & $\begin{array}{l}(+) \\
\text { related } \\
(+) \\
\text { related }\end{array}$ \\
\hline Sirgy et al. [13] & $\begin{array}{l}\text { Self-image } \\
\text { congruence }\end{array}$ & Attitude attention & $\begin{array}{l}(+) \\
\text { related }\end{array}$ \\
\hline Sirgy and Su [18] & Destination image & Travel behavior & $\begin{array}{l}(+) \\
\text { related }\end{array}$ \\
\hline Islam et al. [11] & $\begin{array}{l}\text { Self-image } \\
\text { congruence } \\
\text { Functional } \\
\text { congruence }\end{array}$ & & $\begin{array}{c}(+) \\
\text { related } \\
(+) \\
\text { related } \\
(+)\end{array}$ \\
\hline Kang et al. [8] & $\begin{array}{l}\text { Self-image } \\
\text { congruence }\end{array}$ & $\begin{array}{l}\text { Continued online service usage intention perceived usefulness and } \\
\text { perceived enjoyment }\end{array}$ & $\begin{array}{l}\text { related } \\
(+) \\
\text { related } \\
(+) \\
\text { related }\end{array}$ \\
\hline
\end{tabular}

average of $77 \%$ of all millennials possess smartphones [32]. This demographic group spends more than five hours a day using electronic devices, and Kang et al. [33] noted that $87 \%$ of mobile time is used on mobile applications. Applications enable users to assert their self-concept $[34,35]$. The activity provides identity and functional assistance and opportunities to be involved in a smooth experience. However, Chen et al. [1] claimed that out of millions of apps on various stores, two-thirds are seldom downloaded. As a result, scholars wanted to conduct research and understand the phenomenon of app intention to use. By conducting a metaanalysis of technology adoption factors published between 2008 and 2016, Hew [36] concluded that more than half of the studies used TAM to support their theoretical contributions. The most frequently used constructs for intention to use were perceived usefulness (PU) and perceived ease of use (PEOU). Therefore, many research studies of IS are mainly based on TAM $[3,5]$. TAM contributes to the utilitarian attribute model, concentrating on related functional characteristics (e.g., PU and PEOU) [24, 37-41]. For instance,
Joo and Sang [6] found that PU has a direct influence on app continuance intention. Lin and Kim [5] conducted a similar study and confirmed that PEOU, privacy concerns, and intrusiveness concerns have a positive association with attitude toward app usage. Furthermore, McLean et al. [26] found that utilitarian factors are influential in $\mathrm{m}$-commerce engagement.

Konok et al. [42] noted that mobile attachment through various apps among young adults is a primary means to store old memories and socially connect with the outer world. Therefore, the downloaded app is used to represent the virtual social identity of the users. Japutra et al. [7] and Islam [11] suggested that individuals exhibit conformity behavior by using the products and services that are congruent with the image of a social group that people aim to participate in. For example, past research suggests that individuals were recognized based on their possessions [43-45]. Similarly, the present research makes the assumption that the users are recognized based on the app they use in an online environment. Therefore, an individual's social self-concept and 
self-image congruence could be affected by their app intention to use and consumption decisions. Consequently, the present study based on the self-congruity theory hypothesized that self-image congruence might be one of the key determinants of app intention to use. Self-image congruence influences an individual's willingness to buy because one prefers goods or services that are congruent with one's image [46]. Image congruence, self-image congruence, and self-congruity are used reciprocally in the marketing and hospitality literature $[18,47,48]$. The literature on the association between self-congruence and technology intention to use, such as app intention to use, is also limited.

The current research takes a unique approach in investigating the determinants of the mobile app intention to use with the self-congruity theory from self-image congruence and functional congruence. The present research provides a comprehensive review of the extant literature on self-image congruence and functional congruence and develops a conceptual model of the mobile app intention to use in the IS. Leveraging the lens of self-congruity and TAM theories, this conceptual framework examines, with the best of our knowledge, the role of self-image congruence on mobile app intention to use.

This research contributes theoretically to the extant literature of attitude to adopt the mobile app by using the self-congruity theory and offers the comprehensive framework of mobile app intention to use with its antecedents. In addition, we also contribute to app adoption by determining the role of self-image congruence, actual self-concept, and the ideal self-concept in the context of mobile app intention, a relationship that has been overlooked (see in Table 1). Furthermore, in using the selfcongruity theory, we extend the past literature in the sense that, along with the functional features (i.e., PU and PEOU), self-image congruence (actual and ideal selfconcept) is essential for mobile intention to use. In addition, this study advances the understanding that selfimage congruence has significant importance in the context of mobile app intention to use. This study provides the empirical evidence to the proposed conceptual framework that self-image congruence along with functional congruence significantly and positively influences the mobile app intention to use in the IS. Finally, for practice, this research propose findings that provide suggestions to the app developers, digital marketers of the various mobile apps, and the policymakers that can help them understand that self-concept of the users is equally essential in mobile app intention to use.

This study is organized as follows. Section 1 discusses the importance and research significance of the paper. Section 2 provides the theoretical and literature support of the proposed hypotheses. Section 3 exhibits the methodology, such as data collection and explanation of the data analysis technique used in this article. Section 4 demonstrates the complete results of this paper. Finally, Section 5 discusses the results and explains the theoretical and practical implications. In addition, this section also identifies the limitation as well as explains the proper suggestion for future studies.

\section{Theoretical Framework}

Self-concept has been considered as an advanced, useful construct for understanding and predicting consumer behavior $[9,11,49]$. Scholars referred to self-concept as selfimage; it has been proposed that individuals choose brands or products that are aligned with their self-image [50, 51]. It has been defined as "the totality of an individual's thoughts and feelings having reference to himself as an object" $[7,52]$. The consumer behavior literature accepts the hypothesis that individual self-concept (i.e., self-image) forecasts particular buying behavior $[18,53]$. Self-concept distinguishes into two facets: ideal and actual self-concepts [16]. The extant literature widely examined the effect of actual self and the ideal self on individual choice behavior [7], where actual self shows the state in which individuals recognize themselves who they are and ideal self symbolizes the state of individuals' ambitions of their idea in the coming future. According to Ekinci and Riley [54], actual and ideal self-concept provides the theoretical foundation to the self-congruity theory. Aaker [55] and Sirgy [53] found that self-congruence mentions the tendency to fit between customer self-concept and brand personality.

Scholars agreed that the influence of self-image congruence on individual purchase decisions had been theoretically explained by the self-congruity theory $[11,16,50]$. This theory suggests that individuals choose to buy and use products that have a symbolic and functional congruent with their self-concept $[56,57]$. It is because self-congruence (i.e., self-image and functional congruity) stimulates buying behavior. According to Johar and Sirgy [47], self-congruity can be treated as a logical extension of self-concept. This concept proposes that the higher the degree of congruence, the greater the chance of willingness to purchase [50].

This research further explains the mechanism through which the functional factor relates to mobile app intention to use. For instance, Ahn et al. [46] found that functional congruity denotes the perfect characteristics of a customer looking for a product. This study explained that products and services are dependent on the various attributes that matter to individuals. The IS literature has widely studied the determinants of the mobile/app adoption [3, 4, 6, 24, 58, 59]. Also, TAM has hypothesized basic variables (i.e., PU and PEOU) and widely studied to understand the users' behavior in IS due to simplicity and understandability [60]. It has been proposed that $\mathrm{PU}$ and $\mathrm{PEOU}$ are considered as essential determinants of e-commerce adoption or mobile app intention to use [61, 62]. King and $\mathrm{He}$ [37] conducted a metaanalysis on TAM and found that it is a logical, robust, and conclusive model that has been extensively used and has broader acceptability.

In IS research, Davis [63] first time introduced the concept of TAM, which was built on the hypothesis that information and communication technology is welcomed when it is technically excellent and easy to use. Scholars conducted several studies to examine the effect of utilitarian factors on technology acceptance constructs, as shown in Table 2. Similarly, in the case of UTAUT2, the adoption factors centered on functional and social constructs (see in Table 3). Recently, consumer behavior scholars agreed on 
TABLE 2: Past literature of TAM that is responsible for attitude towards using or engagement.

\begin{tabular}{|c|c|c|c|}
\hline Studies & Independent variables & Dependent variables & Findings \\
\hline $\begin{array}{l}\text { Nikou and Economides } \\
\text { [3] }\end{array}$ & $\begin{array}{c}\text { PU } \\
\text { PEOU } \\
\text { Perceived interactivity } \\
\text { Content } \\
\text { Perceived feedback }\end{array}$ & Behavioral intention & $\begin{array}{c}(+) \\
\text { related } \\
(+) \\
\text { related } \\
(+) \\
\text { related } \\
(+)\end{array}$ \\
\hline Abdullah and Ward [4] & $\begin{array}{l}\text { PU } \\
\text { PEOU }\end{array}$ & Attitude towards using, behavioral intention to use, actual use & $\begin{array}{c}\text { related } \\
(+) \\
\text { related } \\
(+)\end{array}$ \\
\hline Lin and Kim [5] & $\begin{array}{l}\text { PU } \\
\text { PEOU }\end{array}$ & Attitude towards using, purchase intention & $\begin{array}{l}\text { related } \\
(+) \\
\text { related } \\
(+)\end{array}$ \\
\hline $\begin{array}{l}\text { Sánchez-Prieto et al. } \\
\text { [64] }\end{array}$ & $\begin{array}{l}\text { PU } \\
\text { PEOU }\end{array}$ & Attitude towards using, behavioral intention to use, actual use & $\begin{array}{l}\text { related } \\
(+) \\
\text { related } \\
(+)\end{array}$ \\
\hline Moraes et al. [65] & $\begin{array}{l}\text { PU } \\
\text { PEOU }\end{array}$ & Attitude towards using, behavioral intention to use, actual use & $\begin{array}{l}\text { related } \\
(+) \\
\text { related } \\
(+)\end{array}$ \\
\hline Jan and Contreras $[58]$ & $\begin{array}{c}\text { PU } \\
\text { PEOU }\end{array}$ & Attitude towards using, behavioral intention to use, actual use & $\begin{array}{l}\text { related } \\
(+) \\
\text { related } \\
(+)\end{array}$ \\
\hline McLean et al. [26] & $\begin{array}{c}\text { PU } \\
\text { PEOU } \\
\text { Enjoyment } \\
\text { Convenience }\end{array}$ & $\begin{array}{l}\text { Engagement with branded mobile application, attitude towards the } \\
\text { brands, brand loyalty }\end{array}$ & $\begin{array}{c}\text { related } \\
(+) \\
\text { related } \\
(+) \\
\text { related } \\
(+)\end{array}$ \\
\hline $\begin{array}{l}\text { Mortenson and Vidgen } \\
{[66]}\end{array}$ & $\begin{array}{l}\text { Literature review based on } \\
\text { TAM }\end{array}$ & & $\begin{array}{l}\text { related } \\
(+) \\
\text { related } \\
(+)\end{array}$ \\
\hline Park et al. [67] & $\begin{array}{l}\text { PU } \\
\text { PEOU }\end{array}$ & Actual use & $\begin{array}{l}\text { related } \\
(+) \\
\text { related } \\
(+)\end{array}$ \\
\hline Joo and Sang [6] & $\begin{array}{l}\text { PU } \\
\text { PEOU }\end{array}$ & Intention to use & $\begin{array}{l}\text { related } \\
(+) \\
\text { related }\end{array}$ \\
\hline
\end{tabular}

that app intention to use, and app engagement is not only measured by technical constructs but also by psychological factors [70, 74, 75]. The extant literature on technology acceptance and app adoption has primarily concentrated on TAM and acceptance of the real contribution of this research based on the symbolic congruence and its potential effects on the app adoption. In other words, functional congruity is not only the key determinant that influence user attitude towards app adoption but also self-image congruence may be equally important, which users use to evaluate the app's features.

From Tables 1-3, it can be concluded that there had been less research where TAM has been explored with the selfimage concept, presented in Figure 1. Moreover, IS scholars added various constructs to TAM and UTAUT2 frameworks based on convenience, ease of use, and effort expectancy. In this research, we continue to examine the technology acceptance or app intention to use factors by revisiting the 
TABLE 3: Framework based on the UTAUT1 and UTAUT2 responsible for behavioral intentions.

\begin{tabular}{lccc}
\hline Studies & Independent variables & Dependent variables & Findings \\
\hline Šumak and Šorgo [68] & PE, EF, SI, FC & Behavioral intention & $(+)$ related \\
Khalilzadeh et al. [69] & PE, EF, SI, FC & Attitude, behavioral intention & Behavioral intention \\
Parameswaran et al. [25] & PE, EF, SI, FC & Behated \\
Im et al. [70] & PE, EF, SI, FC & Beharal intention, behavioral use & $(+)$ related \\
Magsamen-Conrad et al. [71] & PE, EF, SI, FC & Behavioral intention & $(+)$ related \\
Casey and Wilson-Evered [72] & PE, EF, SI, FC, HM, WI & Behavioral intention & $(+)$ related \\
Sheikh et al. [24] & PE, EF, SI, FC, HM, PSO, habit & Behavioral intention & $(+)$ related \\
Macedo [73] & PE, EF, SI, FC, HM, PSO, habit & Behavioral intention & $(+)$ related
\end{tabular}

$\mathrm{PE}=$ performance expectancy; $\mathrm{EF}$ = effort expectancy; $\mathrm{SI}$ = social influence; $\mathrm{FC}=$ facilitating condition; $\mathrm{HM}=$ hedonic motivation; $\mathrm{PSO}=$ price saving orientation; $\mathrm{WI}=$ web innovativeness.

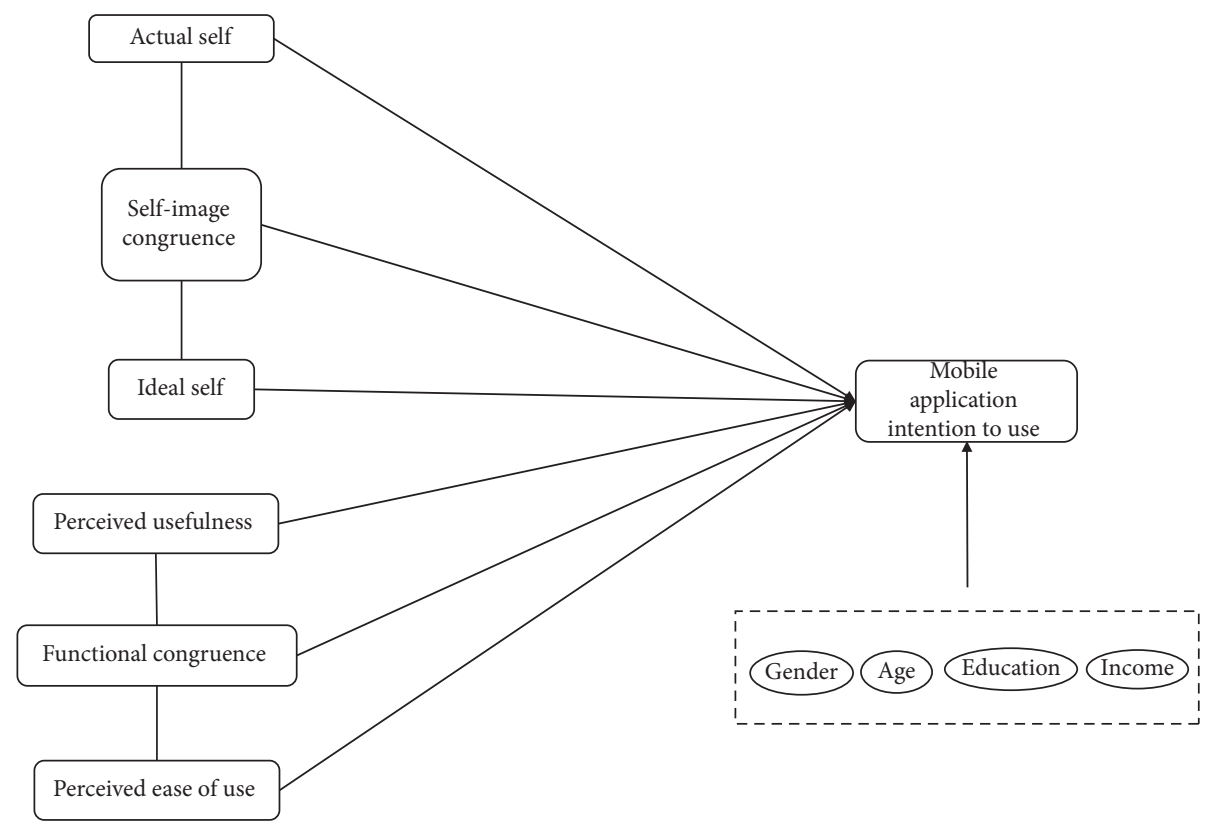

FIgURE 1: Conceptual framework.

TAM based on self-congruity theory which includes selfimage congruence.

\subsection{Hypotheses Development}

2.1.1. Self-Image Congruence. The modern literature has unveiled unique ways that individuals prefer products and services related to a set of personality traits compatible with their own self-image $[18,51]$. Sirgy and Su [18] found selfcongruity in the tourism sector to explain tourist behavior. Additionally, Murphy et al. [76] suggested an integrative framework building the association among self-congruence, destination image, and tourists' behavior. Sirgy and Su [18] showed the self-image congruence role in forecasting the destination selection. This study found that the customer's attitude towards goods or services is determined by matching the product shopper's image with the individual's self-concept. The higher the match between the product user image and individual self-concept, the more probable that the user has a supportive attitude towards that particular product. The matching process is mentioned as self-image congruence [50].

Scholars used product image directly to measure the selfconcept because it has considered a construct that impacts the process of buying where to purchase $[11,77]$. Johar and Sirgy [47] explained that if the product has a direct personality connection, it has to be bought or acquired noticeably or visibly. One of the initial explanations of this construct was presented by Sirgy [16], who explains that individuals examine the characteristics of the products and brands and that those are incongruent symbolically. Psychologists and marketers agreed that individuals' purchase products and brands for both symbolic meaning and functional value. Kressmann et al. [50] concluded that symbolic consumption mirrors the lifestyle and personality of the customer, revealing social distinctions. For instance, Amaral and Loken [78] found that individuals purchase 
luxury brands to emphasize their social status in society. Consumption or intention to use serves as a vehicle of selfexpression, and individual select brands/products which emotionally align with their self-image. Using particular brands allows the consumer to explain, cultivate, and boost their self-image. Kang et al. [8] researched the continuance intention based on the self-image congruity and regret. This study on IS concluded empirically that self-image congruent plays a significant role in establishing the continuance intention. Islam [11] described that self-image congruence regulates the user's buying motivation because she/he chooses goods or services that are aligned with her/his selfconcept. Johar and Sirgy [47] defined the self-image congruence as "consumers no longer consume products for their material utilities but to consume the symbolic meaning of those products as portrayed in their images and products. The brands become commodity signs." Therefore, this research proposes that self-image congruence may influence the mobile app intention to use. Thus,

$\mathrm{H} 1$ : self-image congruence is positively associated with app intention to use.

Furthermore, the marketing literature has long noted that self-congruity is a multifaceted construct because it has been conceptually associated with distinctly contrary nature, such as actual self-concept, i.e., "how a person sees him/ herself," and ideal self-concept, i.e., "how a person would like to see him/herself" $[10,11,16]$. Self-image congruence indicates a mental match between individual self-concept (e.g., actual self and ideal self) and a user image, brand/product image, destination image, or store image of a given brand/ service/product [7]. This research found that customers purchase brands to disclose their actual and ideal selfconcept. According to Escalas and Bettman [79], self-verification motives have guided an individual to express the actual self, whereas the self-enhancement motive governed to express the ideal self-concept. Besides, Kressmann et al. [50] found that consumer brand relations improved when products or services are capable of fulfilled self-verification and self-enhancements motives. Therefore, the higher the congruence between apps image and actual or ideal self, the greater the emotional connection towards the app. Past research suggests that users of various social networking sites are connected to social media when apps reputation is compatible with self-image, actual, or ideal self-concept $[80,81]$. The present research hypothesizes that a higher level of self-image congruence, actual self, and ideal self may enhance the degree for users to use particular mobile apps. Thus, we propose the following hypotheses:

H1a: actual self-image is positively associated with app intention to use

H1b: ideal self-image congruence is positively associated with app intention to use

2.1.2. Functional Congruence. TAM has been extensively researched to explain the user's decision-making process to welcome advanced technology $[4,67]$. According to Wallace and Sheetz [61], TAM has high credibility and has been utilized in various user technology adoption studies. For example, McLean et al. [26] explained that TAM is providing the best theoretical foundation to understand and forecast the process of user adoption or acceptance of new technology because it explains the functional factors influencing the technology adoption. According to Sirgy et al. [82], functional congruence is dependent on the goods or services perceived functional characteristics associated with the individual's desired performance. Hung and Petrick [83] explained the critical role of the functional congruence in forecasting various customer behaviors indicated as product choice, attitude towards use the goods, and brand choice. Additionally, Ahn et al. [46] defined functional congruity in the hospitality sector as "the match between the beliefs of the product's utilitarian attributes (performance-related) and the audience's referent attributes." Simply, the destination's functional congruence influenced the overall destination performance. Johar and Sirgy [47] found that functional congruence is a mixture of product constructs positively related to the customer's expected performance. In information system research, functional congruence, functional attributes, website quality factors, and variables affect the technology acceptance in app engagement [3-5]. Therefore, this study hypothesized that functional congruence may significantly associate with mobile app intention to use. Consequently,

$\mathrm{H} 2$ : functional congruence is positively associated with mobile app intention to use.

In addition, past research measured the TAM through two important behavioral beliefs that influence behavioral intentions: PU and PEOU. Akman and Mishra [60] found that PU and PEOU are the key antecedents of the individual's acceptance of new technology. PU defined a tendency to which the user admits that using a specific system will improve his/her performance [3]. Similarly, Abdullah and Ward [4] defined PEOU as "the degree to which a person believes that using a particular system would be free of effort." TAM has been widely tested for user acceptance of new technology of different techniques, including e-learning, new media adoption [5], and smartphones. In the social commerce-related research, TAM was applied to examine the determinants and outcomes of mobile app engagement [26], mobile app effectiveness, e-learning adoption [4], mobile acceptance technology among teachers [84-86], acceptance of teleconferencing systems among employees [67], and smartphone usage and adoption among Korean [6]. The findings of these studies exhibit that the PU and PEOU are significant antecedents of user acceptance of new technology-based mobile applications. According to Lai and Li [62], PU and PEOU are considered primary parts of the TAM. Thus, present research broadens the theoretical contribution related to the mobile application through the functional (e.g., PU and POEU) congruence. Therefore, we hypothesized that PU and PEOU lead to app adoption: 
$\mathrm{H} 2 \mathrm{a}$ : PU is positively associated with app intention to use

$\mathrm{H} 2 \mathrm{~b}$ : PEOU is positively associated with app intention to use.

\section{Methodology}

3.1. Research Setting. The present study targets Chinese respondents as a research setting for different reasons. First, China has the most significant smartphone users around the globe, with an estimated 800 million smartphone users using different company's brands. According to App Annie [32], total app downloads exceed 113 billion, and China accounted for approximately $50 \%$ of total downloads, with an estimated $\$ 76$ billion user spending noticed. By the end of 2022, China will continue the world leader by a massive difference in downloading the mobile app. In 2018, the mobile average app revenue per user was 53.1 RMB (\$7.5) and consistently increased compared with the last year. Second, China ICT plays a significant role in the nation's development, such as the financial sector, employment creation not locally but also globally, and the most important $\mathrm{m}$-commerce. The abrupt increase in the smartphone is responsible for China's social commerce success, which is an estimated 2.07 trillion RMB at the end of 2019. Finally, Chinese policymakers in collaboration with professional people introduced the polices which are in favor of the user, developers, and government. In addition, the China government took serious measures against the apps that are not congruent with the cultural and social values. The growing competition in the mobile app business encourages developers to find out the key reasons for app intention to use. Thus, the current research collects data from the Chinese user to achieve the study objectives.

3.2. Survey. In the current research, the survey method was chosen to examine this conceptual framework. We select the survey method because the quantitative approach forecasts individual behavior and investigates the association between variables and constructs [87-89]. Past research proposes that the survey method has been extensively used in examining the user behavior in $\mathrm{m}$-commerce $[24,87,90]$. To collect the survey method, a self-administered survey was used for this study. Our target population consists of users who own smartphones and experience of different apps. In addition, a self-administered survey has various benefits such as broad reach, asking respondents' willingness to fill the questionnaire, and asking the experience of using different apps.

3.3. Measures. In this research, the constructs used in the final survey were adopted from the past literature to match the situation of technology acceptance. This study followed the commonly confirmed suggestion on the wording of items when modifying and developing the final questionnaire. Self-congruity has two facets: actual self-concept and ideal self-concept. In addition, six items adapted and modified from Japutra et al. [7] and Sirgy et al. [91] were used to measure the actual and ideal self-concept. Functional congruence is conceptualized based on the multiattribute model via utilitarian characteristics, which refers to convenience, performance or quality, reliability, and good customer service. In addition, PU and PEOU were adapted and modified by using the six items, respectively, from Davis [63]. The app intention to use was measured by using three items from Chopdar et al. [92] (see in Table 4).

Participants accessed the scenario and questionnaire through the survey designed. After reading a brief introduction and answering some personal questions regarding demographic before completion of the questionnaire, participants were assigned to a scenario: "Please, take a moment and think about the app and then explain this app based on the self-image congruence and functional congruence using one or more features congruent with your self-concept." After reading the scenario paragraph, participants were asked to answer the questionnaire items on a 7-point Likert scale anchored by $(7)=$ strongly agree and $(1)=$ strongly disagree.

3.4. Data Collection. We used a convenience sampling technique for data collection. The participants, who responded belonging to various professions such as university professors, students, organization employees, and the general public, were asked to provide their feedback against the final questionnaire. Before the final questionnaire rotation, we evaluated the content validity. According to Polit and Beck [93], content validity is one of the problematic techniques, especially in those locations where English is not the primary language, and there is a possibility that the context of the study might be changed during data collection. To ensure content validity, the literature on the existing constructs and pilot testing of the instrument were done. All variable items were initially adapted in English. This research targets Chinese smartphone users and asking regarding the app intention to use. The measures included in the conceptual framework were adapted from the past literature and constructed initially in English. The Chinese version of the questionnaire was developed by the generally used translation-back translation procedure $[24,94]$. The final instrument rotated among participants has experienced in using various apps. The questionnaires were distributed through the self-administered survey method to the individuals. In total, 275 questionnaires were distributed, and the respondents returned 251. Of these, 241 were included for final data analysis and remaining were dropped due to the missing values and biased responses. Table 5 shows the demographic profiles of the participants.

\section{Results}

To test this research structure and measurement model, we employed structural equation modeling using the AMOS (version 24.0) software. AMOS is an effective method, which integrates the principal component analysis (CFA) and regression to evaluate the measurement and structural model [88] concurrently. Von der Heidt and Scott [95] 
TABLE 4: Scale items.

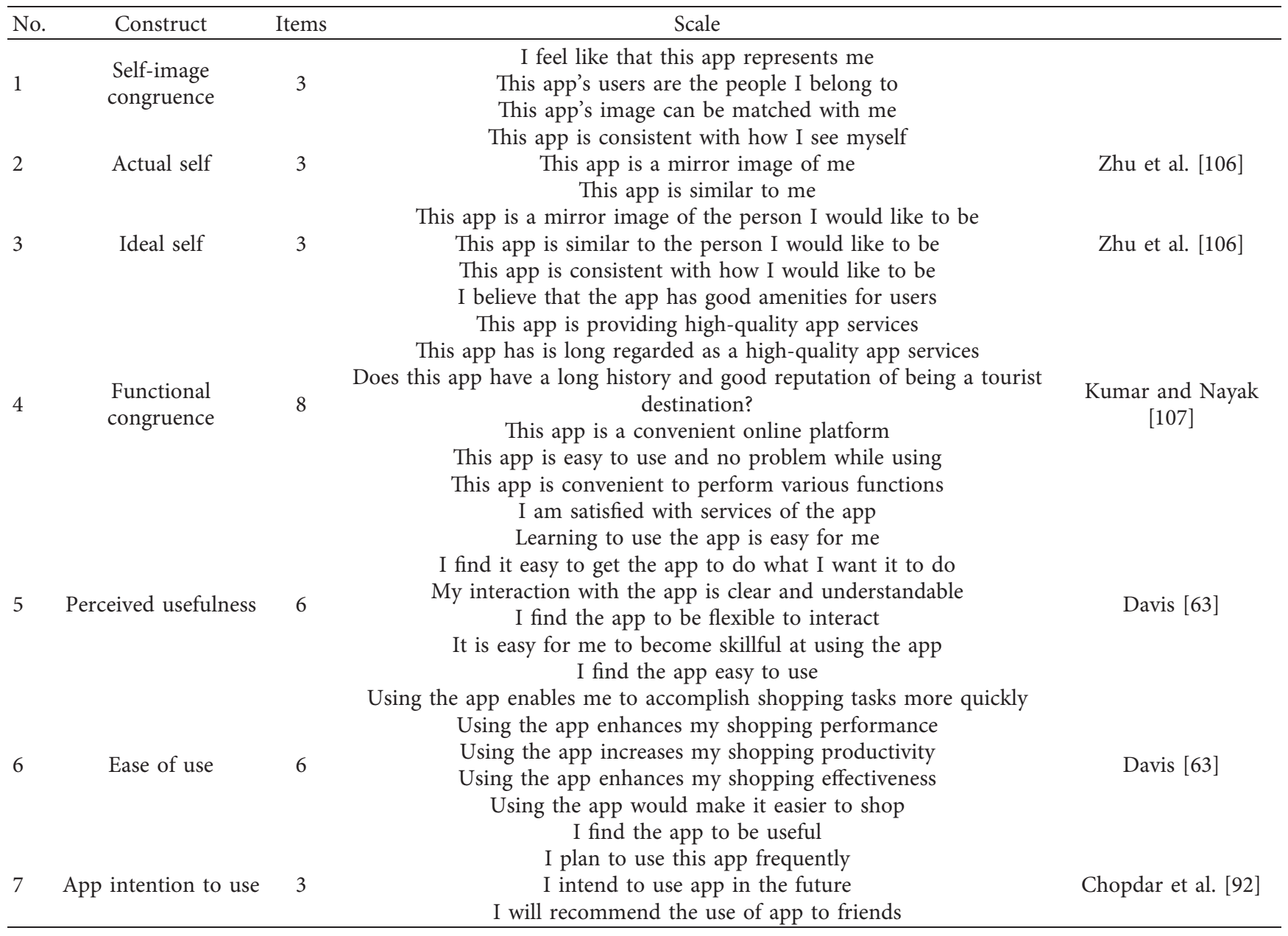

TABLE 5: Sample demographic information.

\begin{tabular}{lcc}
\hline & $n$ & $\%$ \\
\hline Gender & 159 & \\
Male & 82 & 65 \\
Female & & 35 \\
Age & 107 & \\
18-25 & 85 & 11 \\
$26-30$ & 14 & 43 \\
$>30$ & 49 & \\
Education & 39 & 16 \\
College & 166 & 68 \\
Masters & 36 & 16 \\
Postgraduate or higher & & 48 \\
Income & 116 & 31 \\
RMB 0-10,000 & 77 & 19 \\
RMB 10001-20,000 & 48 & \\
RMB $>20,001$ & & \\
\hline
\end{tabular}

assumed that AMOS is capable of measuring the developmental conceptual model but also asks for fewer requirements to validate the conceptual framework. Therefore, this research used AMOS software to investigate CFA and structural models in this research.
4.1. Measurement Model. The present research conceptual model was examined in two steps: the measurement model and the structural model. Based on [96], the present research measurement model was measured through confirmatory factor analysis (CFA). Convergent validities were measured by examining the values of Cronbach's alpha, factor loadings, composite reliability (CR), and average variance (AV). The values of Cronbach's alpha, CR, and AV are 0.70, 0.70, and 0.5 , respectively. The results of CFA display that all item factor loadings are higher than 0.70. As displayed in Table 5, the earlier mentioned values (i.e., Cronbach's, CR, and AVE) are above the minimum threshold. Thus, the results show that the conceptual model has internal consistency and good convergent validity. Also, according to the Gefen and Straub [97], discriminant validity concludes about the measures whether constructs of the conceptual model are different from each other. Discriminant validity was examined by analyzing the association between correlation among variables and square roots of the AVE of the variables [98]. As per Hair et al. [96], if the square roots of the AVE are greater than correlation, demonstrating good discriminant validity is shown in Table 6. In our case, convergent validity is higher than the minimum threshold. Moreover, the correlation 
TABLE 6: Mean, standard deviation, Cronbach's alpha, CR, and AVE.

\begin{tabular}{|c|c|c|c|c|c|}
\hline Constructs & Mean & $\mathrm{SD}$ & Cronbach's alpha & CR & AVE \\
\hline Actual self & 3.6445 & 0.79784 & 0.907 & 0.907 & 0.765 \\
\hline Idea self & 3.7746 & 0.63638 & 0.792 & 0.798 & 0.570 \\
\hline Self-image congruity & 3.5214 & 0.6559 & 0.769 & 0.772 & 0.531 \\
\hline Perceived usefulness & 3.8368 & 0.75176 & 0.947 & 0.943 & 0.733 \\
\hline Perceived ease of use & 3.6715 & 0.67622 & 0.897 & 0.892 & 0.581 \\
\hline Functional congruence & 3.9761 & 0.56844 & 0.893 & 0.893 & 0.512 \\
\hline App intention to use & 3.4326 & 0.63317 & 0.812 & 0.813 & 0.521 \\
\hline
\end{tabular}

TABLE 7: Correlation.

\begin{tabular}{|c|c|c|c|c|c|c|c|}
\hline Constructs & 1 & 2 & 3 & 4 & 5 & 6 & 7 \\
\hline (1) Actual self & 0.874 & & & & & & \\
\hline (2) Idea self & -0.129 & 0.755 & & & & & \\
\hline (3) Self-image congruity & 0.268 & 0.258 & 0.729 & & & & \\
\hline (4) Perceived usefulness & -0.025 & 0.223 & 0.114 & 0.856 & & & \\
\hline (5) Perceived ease of use & -0.045 & -0.002 & -0.035 & 0.055 & 0.762 & & \\
\hline (6) Functional congruence & 0.018 & 0.127 & -0.088 & 0.178 & 0.410 & 0.715 & \\
\hline (7) App intention to use & 0.165 & 0.232 & 0.245 & 0.300 & 0.294 & 0.312 & 0.722 \\
\hline
\end{tabular}

Note: diagonal values are square roots of AVE and off-diagonal values are the estimates of intercorrelation between the latent constructs.

TABle 8: Cross loading.

\begin{tabular}{|c|c|c|c|c|c|c|c|c|}
\hline Constructs & Items & 1 & 2 & 3 & 4 & 5 & 6 & 7 \\
\hline \multirow{3}{*}{ (1) Self-image congruence } & SIC1 & 0.784 & 0.013 & 0.047 & 0.031 & 0.027 & -0.097 & -0.013 \\
\hline & SIC2 & 0.728 & -0.066 & -0.063 & -0.004 & -0.005 & 0.036 & 0.044 \\
\hline & SIC3 & 0.655 & 0.053 & -0.022 & -0.004 & 0.014 & 0.082 & -0.017 \\
\hline \multirow{6}{*}{ (2) Perceived usefulness } & PU1 & -0.049 & 0.844 & 0.003 & 0.001 & 0.020 & -0.057 & 0.059 \\
\hline & PU2 & -0.070 & 0.841 & -0.012 & 0.026 & 0.011 & 0.037 & 0.074 \\
\hline & PU3 & -0.028 & 0.930 & 0.005 & -0.007 & -0.008 & 0.007 & -0.030 \\
\hline & PU4 & 0.016 & 0.919 & 0.029 & -0.004 & 0.009 & -0.014 & 0.010 \\
\hline & PU5 & 0.079 & 0.854 & 0.010 & 0.015 & -0.008 & -0.022 & -0.033 \\
\hline & PU6 & 0.050 & 0.797 & -0.029 & -0.045 & -0.028 & 0.064 & -0.077 \\
\hline \multirow{6}{*}{ (3) Perceived ease of use } & PEU1 & 0.004 & -0.019 & 0.060 & 0.720 & -0.007 & -0.037 & 0.012 \\
\hline & PEU2 & -0.046 & -0.071 & -0.019 & 0.821 & 0.047 & 0.095 & 0.017 \\
\hline & PEU3 & -0.010 & 0.118 & 0.022 & 0.746 & 0.010 & 0.033 & -0.013 \\
\hline & PEU4 & 0.018 & 0.034 & -0.011 & 0.781 & -0.031 & -0.027 & 0.011 \\
\hline & PEU5 & -0.015 & -0.009 & 0.023 & 0.814 & -0.017 & -0.006 & -0.046 \\
\hline & PEU6 & 0.069 & -0.057 & -0.035 & 0.720 & -0.002 & -0.011 & 0.002 \\
\hline \multirow{8}{*}{ (4) Functional congruence } & FC1 & -0.079 & -0.058 & 0.674 & 0.094 & 0.011 & 0.000 & 0.008 \\
\hline & FC2 & -0.072 & -0.037 & 0.671 & 0.049 & 0.004 & -0.009 & -0.011 \\
\hline & FC3 & -0.001 & -0.001 & 0.636 & 0.141 & -0.041 & -0.097 & -0.036 \\
\hline & FC4 & 0.042 & 0.071 & 0.612 & -0.006 & -0.028 & 0.012 & -0.013 \\
\hline & FC5 & 0.108 & -0.009 & 0.769 & -0.058 & -0.032 & 0.114 & 0.017 \\
\hline & FC6 & -0.070 & 0.001 & 0.786 & -0.083 & -0.026 & 0.034 & 0.020 \\
\hline & FC7 & 0.040 & 0.038 & 0.784 & -0.028 & 0.028 & 0.022 & -0.047 \\
\hline & FC8 & 0.002 & -0.001 & 0.764 & -0.031 & 0.086 & -0.071 & 0.057 \\
\hline \multirow{4}{*}{ (5) App intention to use } & MAA1 & 0.114 & -0.035 & 0.087 & -0.022 & -0.101 & 0.716 & -0.006 \\
\hline & MAA2 & -0.060 & 0.059 & -0.057 & -0.016 & 0.073 & 0.722 & -0.042 \\
\hline & MAA3 & -0.015 & -0.017 & 0.005 & -0.003 & 0.005 & 0.728 & 0.023 \\
\hline & MAA4 & -0.025 & 0.006 & -0.019 & 0.088 & 0.030 & 0.699 & 0.047 \\
\hline \multirow{3}{*}{ (6) Actual self } & AS1 & 0.004 & 0.024 & -0.027 & -0.013 & 0.852 & 0.044 & -0.015 \\
\hline & AS2 & 0.021 & -0.045 & 0.087 & -0.091 & 0.890 & -0.026 & -0.018 \\
\hline & AS3 & 0.008 & 0.016 & -0.046 & 0.098 & 0.878 & -0.004 & 0.029 \\
\hline \multirow{3}{*}{ (7) Ideal self } & IS1 & 0.098 & 0.045 & 0.014 & 0.083 & -0.014 & -0.106 & 0.800 \\
\hline & IS2 & -0.072 & -0.014 & -0.010 & -0.066 & -0.018 & 0.071 & 0.814 \\
\hline & IS3 & -0.005 & -0.025 & 0.000 & -0.029 & 0.027 & 0.046 & 0.644 \\
\hline
\end{tabular}


values are presented in Table 7. Moreover, cross loadings of all constructs are shown in Table 8.

4.2. Common Method Variance. The extant literature proposed that there is a probability of happening of common method variance (CMV) when research data were self-reported and acquired from the same scale at the same time. CMV can influence the results of social science; therefore, it is essential to address the problem that might be raised as an issue and the threat to the validity of the results. Past research suggests various techniques to measure the CMV in a data file. Thus, this research uses Herman's single factor test technique to examine the CMV because it is extensively used in social research. According to this technique, CMV has no problem to be used in this research as the first-factor value is less than fifty percent. In our data set, the value of the first factor is 21.033 percent, which is less than the threshold value.

4.3. Structural Model. The proposed hypotheses of the conceptual framework were all measured in the second step by using the AMOS. Initially, the structural model fit indices lie within their suggested range as follows: $\chi 2=588.363$, d.f. $=465, \quad$ RMSEA $=0.033, \quad C F I=0.973, \quad R F I=0.868$, and NFI $=0.884$. Thus, it consecutively supports the goodness of fit obtained for the structural model [96]. The main aim of this research is to investigate the effect of self-image congruence and functional congruence on users' app intention to use. The results shows that self-image congruence $(\beta=0.141$ and $p<0.01)$, actual self-concept $(\beta=0.204$ and $p<0.01)$, and ideal self-concept $(\beta=0.232$ and $p<0.01)$ have a positive influence on the app intention to use. Thus, H1, $\mathrm{H} 1 \mathrm{a}$, and $\mathrm{H} 1 \mathrm{~b}$ are supported. Moreover, the results show that functional congruence $(\beta=0.167$ and $p<0.01)$ PU $(\beta=0.101$ and $p<0.001)$, and PEOU $(\beta=0.314$ and $p<0.001)$ have positive on the app intension to use. So, $\mathrm{H} 2$, $\mathrm{H} 2 \mathrm{a}$, and $\mathrm{H} 2 \mathrm{~b}$ are supported as shown in Figure 2. Additionally, the three control variables (gender, age, and education) were insignificantly associated with app intension to use, as shown in Table 9.

\section{Discussion}

The present study first evidenced through empirical examination and validated that self-image congruence is a key antecedent of mobile app intention to use. To date, the extant literature has been centered on the functional factors related to the mobile app intention to use $[64,99]$. The primary objective of this research is to extend the role of self-image in measuring the mobile app intention to use in the digital environment based on the self-congruity theory from the context of the social self-concept. The findings reveal that self-image and functional congruence were found to influence the mobile intention to use as proposed by the conceptual framework. Simply, it means that in the digital environment, self-congruity from symbolic congruence plays a significant role in using the mobile app, and online users along with the functional feature are also concerned about the symbolic meaning of the mobile app. In addition, there are two main effects that influence the mobile intention to use. One is that users can consider the functional attributes of the mobile app and decide to download or create a profile on it [3]. The other is that online users see the symbolic meaning of a particular app. Furthermore, these research findings are quite unique and first found that symbolic congruence has equal weight like functional congruence.

Based on the self-congruence theory, the present theoretical framework divided independent constructs into two: self-image congruence and functional congruence. The findings of our research reveal that self-image congruence has a significant influence on the app intention to use, and the path coefficient of the actual self-concept has a significant high value as compared with other determinants with app adoption. It means that image congruence is equally important to accept new technology. In the online environment, users are much careful while downloading the app recommended by peers or from the app store and also concerned about image congruence in addition to functional congruence. The extant literature on technology acceptance and app adoption has primarily concentrated on utilitarian attributes models such as TAM and UTAUT2 [21, 64, 73]. McLean [100] claimed that an abrupt increase in the global adoption of smartphones directly influenced app engagement and considered it an important marketing tool for organizations and has a positive effect on firm performance, brand loyalty, and customer loyalty. The study found that functional congruence such as PU and PEOU positively related to the app intention to use the results that are aligning with the extant literature. Besides, self-image congruence impact on app adoption is highly significant than functional congruence.

Furthermore, the result of hypotheses $\mathrm{Hla}$ and $\mathrm{H} 1 \mathrm{~b}$ shows the significant influence of actual and ideal selfconcept on the mobile app intention to use. When the user is perceived high congruence of actual and ideal self-concept with the mobile app, online users are more probable to use the particular app. Additionally, self-image congruity from actual and ideal self-concept drives a user to adopt the specific app in the online environment context, and this intention to use was made after full deliberations of impression management and social identity.

Moreover, the findings enlighten which type of congruence is more important for mobile app intention to use. Our result shows that both facets of the self-congruity theory have a significant effect on app intention to use. Consistent with past studies results, the result display that the actual self is a significant predictor of app intention to use. Past research suggests that self-congruence is used to predict consumer behavior. Individuals consume services/products/ services for both functional value and symbolic representations. Sirgy et al. [91] found that individuals purchase brands not only for what functions they perform but also what they mean. Similarly, particular app usage represents the user's personality attributes and social patterns [75]. In an online environment, the use of a particular app reflects the personality and individual behavior. For instance, they 


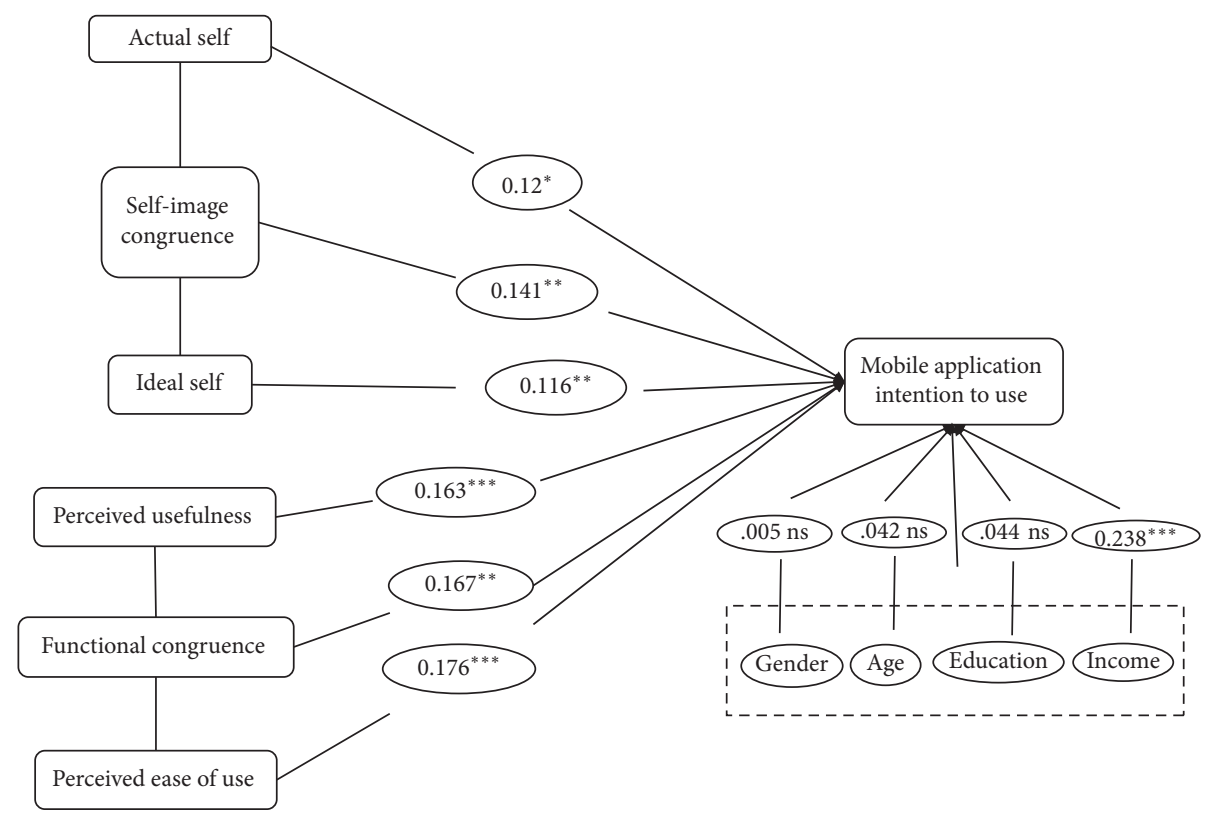

Figure 2: Validation of the conceptual model. Note: ${ }^{*} p<0.05,{ }^{* * *} p<0.001$, and ns $=$ nonsignificant.

TABLE 9: Results of standardized estimates of the structural model.

\begin{tabular}{lcccc}
\hline Path & $\begin{array}{c}\text { Path coefficient } \\
\text { value }\end{array}$ & SE & CR & $p$ value \\
\hline SIC $\longrightarrow$ app & 0.141 & 0.056 & 2.498 & 0.012 \\
$\mathrm{AS} \longrightarrow$ app & 0.121 & 0.046 & 2.623 & 0.009 \\
$\mathrm{IS} \longrightarrow$ app & 0.116 & 0.058 & 2.011 & 0.044 \\
$\mathrm{FC} \longrightarrow$ app & 0.167 & 0.067 & 2.483 & 0.013 \\
$\mathrm{PU} \longrightarrow$ app & 0.163 & 0.048 & 3.396 & $* * *$ \\
$\mathrm{PEOU} \longrightarrow$ app & 0.176 & 0.056 & 3.129 & 0.002 \\
Gender $\longrightarrow$ app & -0.005 & 0.077 & -0.068 & 0.946 \\
Age $\longrightarrow$ app & 0.042 & 0.043 & 0.986 & 0.324 \\
Education $\longrightarrow$ app & -0.044 & 0.063 & -0.703 & 0.482 \\
Income $\longrightarrow$ app & 0.238 & 0.056 & 4.249 & $* * *$ \\
\hline
\end{tabular}

are using a particular app (dating or gaming app) to reflect what type of personality they have [74]. Online use of particular app delivers as a vehicle of self-expression, and users select apps that emotionally align with their selfconcept. The online presence on social apps and continuous usage allow users to express, maintain, and improve their self-concept. Therefore, self-image congruence has a key determinant that may affect app adoption. It is because that usage of particular app expresses user social identity. According to the media practice model, users select the app congruent with their self-identity. For example, users who were low in dating anxiety, non-heterosexual, and held more sexually open-minded had a more tendency to use dating app [74].

Moreover, the current study found that functional congruence (i.e., $\mathrm{PU}$ and $\mathrm{PEOU}$ ) has a significant influence on the app intention to use, consistent with past research $[26,36,60,63]$. The finding reveals that the TAM model was capable of illustrating the app intention to use the framework, such as online studies like e-commerce, banking, and education [3, 4, 67]. For example, McLean et al. [26] researched $\mathrm{m}$-commerce engagement and found that $\mathrm{PU}$ and PEOU have a key role in user app engagement. The app design is a combination of technical or functional factors which are important. While the adoption of the users of the app is less concerned about the complex functional factors, they prefer the app that is easy to use. Therefore, these research findings are consistent with the past literature that $\mathrm{PU}$ and PEOU have a direct influence on the app intention to use.

In conclusion, self-image congruence was found to be a stronger determinant of mobile attention to use. This finding reveals that when online users are willing to download or to think about using the particular app, they will be considered their actual and ideal self-concept; the findings corroborate with the past literature [8]. However, the extant literature in the self-image congruence has investigated brand choice, preference, and loyalty. With the best of our knowledge, this is the first to examine the influence of self-image congruence on the mobile app intention to use. This research concludes that, for online users', self-image congruence is a significant determinant of mobile intention to use similar to the functional congruence and increases the chances to use a particular mobile app. On the other hand, this study through a systematic review of the mobile adoption antecedents confirms that in the past literature, it has been extensively examined the role of functional features in mobile app intention to use or continuance use in the IS (see in Tables 2 and 3). Therefore, based on the self-congruity theory, it extends the existing literature and found a significant role in self-image congruence in predicting the mobile app intention to use. This direct influence of self-image congruence on the mobile intention to use equals the predictive power of functional congruence on the mobile intention to use. Moreover, our 
research findings also extend the TAM model which hypothesized that technological or functional factors influenced mobile adoption behavior. Finally, this research explores the role of self-image congruence in examining the user's mobile intention to use in the IS based on the selfcongruity theory from the perspectives of the self-image congruence. A potential illustration is that self-image congruence is more or equally important for online users' when selecting or downloading the specific mobile app.

\section{Conclusion}

Drawing on the self-congruence theory, this study primarily aims to examine the influence of self-image congruence and functional congruence on the mobile app intention to use. On account of a large number of studies in the IS context that only examined the functional or technological factors responsible for mobile App adoption, the reason behind was found that, in the start, only limited users accessed these specific apps. The abrupt increase in mobile apps due to the web 2.0 initially attracted millions of online users. However, with increasing competition, mobile apps are facing severe issues. For instance, Chen et al. [1] claimed that out of millions of apps on various stores two-third even seldom downloaded. Similarly, Google Play Store holds more than 1 million apps, but more than $90 \%$ of branded apps have been installed less than 50,000 times. Tables 2 and 3 reveal that scholars extensively studied the technology factors and overlooked the symbolic congruence in mobile adoption. With the best of our knowledge, no single study except [8] examined the role of ideal and actual self-concept on mobile adoption. Thus, to measure the empirical validation of the self-image congruence on mobile app intention to use, data were collected from Chinese smartphone users through the survey-based approach. The findings show that self-image congruence is positively significantly related to mobile app intention to use. In addition, based on the TAM, the extant literature has widely studied the functional factor (i.e., PU and PEOU) impact on the technology/app adoption. The current research fills the research gap related to symbolic congruence in the mobile app intention to use. This reveals that symbolic congruence is also an essential factor in adopting particular technology because in the digital environment, online users are very much concerned about their online personality while using various apps. Furthermore, the results show that functional congruence is positively related to mobile app intention to use. Leveraging the lens of the self-congruity theory, the present research extends the theoretical contribution of TAM through empirical examination and provides evidence that symbolic congruence is equally important like PU and PEOU for the mobile app intention use. For app developers and promoters, this research provides the guidelines that self-image has significance importance in the app adoption, and they should focus on such critical factors that previously ignored in the technology acceptance research. Thus, this study helps to provide the basis and create a foundation that helps future researchers.
6.1. Theoretical Contribution. The present research makes a significant contribution to the extant literature of technology adoption. First, the present research contributes to a better understanding of smartphone users' mobile app intention to use by examining specifically the key antecedents of the mobile app adoption. The past literature on the mobile app intention to use regularly targets on the technological or technical factors such as ease of use and PU. Little research has been done to measure the psychological mechanism of the adoption of the mobile app among users'. Leveraging the lens of the self-congruence theory, the present study filled the research gap and explained what other main factors are important for the mobile app intention to use. Furthermore, it incorporated the symbolic and functional congruence to reflect the determinants of mobile app intention to use, which increases the understanding of the symbolic value in app adoption and usage. Through empirical validation, this study admits that the role of symbolic congruence could be important for the mobile app intention use since self-image congruence plays a primary role in mobile app adoption. Moreover, this study contributes to a better understanding of the underlying mechanism of mobile app intention to use.

Second, the extant literature on mobile app adoption has generally been studied based on the TAM and UTAUT2. Although some research has examined the role of the selfimage congruence on the various consumers' buying behaviors, symbolic congruence has still not been examined in the technology adoption, to the best of our knowledge. Therefore, through the empirical investigation, this study contributes to the self-congruence theory by measuring the influence of two facets: functional congruence and selfimage congruence. This research analyzes two main routes through which smartphone users' intention towards the app is changed if one of the facets is not properly congruent with the values of users. Third, the current research advances the better understanding that symbolic and functional have significance importance in the mobile app intention to use. Sirgy et al. [13] highlighted the significance of the self-image congruence in influencing the consumer brand preference in branding the literature. This research extends the research scope of Sirgy et al. [13] by exhibiting that symbolic congruence impacts the mobile App intention to use. Additionally, previous scholars added functional determinants in the technology adoption model. For example, Sundarraj and Manochehri [99] added trust in the online banking context, Junglas and Spitzmuller [101] added privacy as a determinant of PU, Yoon and Kim [102] included habit and convenience in the context of online shipping, and finally Shaw and Sergueeva [103] added perceived value in $\mathrm{m}$-commerce context, a proposed extension of UTAUT2 In addition, our research based on the self-congruence theory extends the adoption model into two determinants. First, technology/ functional constructs are important for technology. Our findings show that PU and PEOU have a significant influence on app intention to use, consistent with the previous literature. Second, the findings of the present study found that self-image congruence plays a significant role in app intention to use. We recognized that self-image congruity plays a significant role in the app intention to use too because 
mobile apps are significant medium, though ICT users' build their virtual/social identities.

Finally, this research extends the existing literature by examining and validating a framework that combines selfcongruity theory drivers on app intention to use. Self-image congruence and functional congruence are confirmed to be significant determinants that forecast the product/brand/ services' choice. As a result, from a theoretical point of view, the present research establishes the validity of the selfcongruence theory in IS. The literature on app intention to use generally uses attitude towards use as a proxy of the actual behavior because the actual behavior is proposed to be influenced by multiple factors $[26,104]$. In this context, we extended from attitude to use to an actual adoption and validated through empirical evidence to reflect the users' actual adoption behavior.

6.2. Practical/Social Implications. The present research findings provide several recommendations to the app developers and people responsible for handling the firm's online communication. First, current research results show that self-image congruity is one of the key determinants that influence the mobile app intention to use. The findings provide the guidelines to the app developer and app promotion manager that image congruence has a primary role in the app preference. Therefore, app developers and social media marketing managers should take care of the user image while developing the mobile app. The app attributes should be personalized to the actual or ideal self-concept of potential online users' because in certain cultures, the individual consumption depends on external factors. For instance, eastern culture is considered as collective and sees the individuals as embedded in a social group, and they are recognized by their social role and in association with other relationships. As a result, individuals are more concerned about social image, especially in China. Thus, it is the primary responsibility of the app developers, and app managers responsible for the promotion of the apps must understand the symbolic meaning of their app.

Second, results widely apply to the manager of all businesses such as m-commerce, hospitality, and finance. Apps have entirely changed the way users connect, shop, and socialize [105]. In addition, Chen et al. [1] claimed that out of millions of apps in various stores, two-thirds are even seldom downloaded. Google Play Store holds more than 1 million apps. Hsu et al. [2] demonstrated that more than $90 \%$ of apps have been installed less than 50,000 times. Therefore, app developers and managers are under an intense burden to understand users' online experiences and the resulting effects on the postpurchase decision. The findings demonstrate that actual and ideal self-image congruity has a significant role in measuring the app intention to use. It provides that app developers and managers need to learn the role of actual self-concept and ideal self-concept in illustrating the user's behavioral intention. Therefore, individuals responsible for online business of the firm should identify the apps that focused on the self-congruity. This activity is beneficial for the people responsible for the app development and successful launching. As a result, the findings of this research are providing a comprehensive detail to the managers to pay proper attention to the tendency to which app's image is congruent with users' identity.

Third, software developers and marketers used app images for brand positioning because online apps generate profits for the firms greater than their offline business. Consequently, app success is directly associated with firm performance. Corporate reputation scholars believed that app reputation is critical in the firm success in the digital business environment and identified the various factors that influence the app reputation such as quality of the app, a feature provided by the retailer, and congruence with local values. As a result, the app image is then assessed in the light of particular components of the user's self-concept to determine the tendency of attitude towards app usage. Previously, all multiattribute attitude models are the evidence that they commonly add only functional or performancerelated characteristics, not identity or image-related aspects, in measuring the brand attitude. Therefore, it would be beneficial for marketing researchers to develop apps that align with individual symbolic and cultural values.

Finally, this research is beneficial for governmental officials of the developing countries where smartphones are penetrating into the individuals' lives and businesses. The government should regulate mobile apps and confirme that these apps are fully congruent with cultural norms and social values of the society. For instance, some of the countries banned Tick-Tok because it is not consistent with local values and dangerous for the users and societal values, which provided empirically evidence that self-image congruence is essential for the mobile app intention to use. Therefore, dealing with a mobile app is a critical process for app developers and the promotion manager. For example, Akman and Mishra [60] found that mobile app usage is positively related to consumer buying intention.

6.3. Limitation and Future Research. Although the present research adds to the body knowledge, it has some limitations. The data were collected from this research from Chinese respondents. Therefore, the findings of this framework could vary in other cultures. It is hard to generalize the findings of this research for users with diverse cultural values, so the research results have limited external validity. The future researcher should reexamine this model in other contexts in order to improve its generalizability. Second, the present study used cross-sectional data. As a result, this study was not able to measure the precise view that demonstrates the true behavior of app adoption. Marketing scholars agreed that consumer behavior fluctuates over time, especially the online information users' behavior. Therefore, future researchers should collect longitudinal research that may help to interpret app users' experiences, satisfaction, and responses over time.

Third, research on the role of the self-congruity on App intention use is our recommendation for future research. Even though our research has demonstrated that self-congruity does play a significant role in app adoption, the study 
does not examine the self-congruence theory's influence on the firm performance, app engagement, and user loyalty through the app adoption. The future study extends this conceptual framework and examines the pivotal role of selfcongruence on the outcome variables individual-wise as well as firm-wise. Finally, future research should also apply this framework on the type of apps such as luxury, entertainment, social, and gaming.

\section{Data Availability}

The data used to support this study are available from the corresponding author upon request.

\section{Conflicts of Interest}

The authors declare that they have no conflicts of interest regarding the publication of this paper.

\section{Acknowledgments}

The work described in this paper was supported by the National Natural Science Foundation of China (NSFC: 71531008, 71521001, and 71490720); the Fundamental Research Funds for the Central Universities (JZ2020HGQB0217); This work has been funded by the China Postdoctoral Foundation grant \# 2020M671235.

\section{References}

[1] Q. Chen, Y. Lu, Y. Gong, and Q. Tang, "Why do users resist service organization's brand mobile apps? The force of barriers versus cross-channel synergy," International Journal of Information Management, vol. 47, pp. 274-282, 2019.

[2] J. S.-C. Hsu, T.-C. Lin, T.-W. Fu, and Y.-W. Hung, "The effect of unexpected features on app users' continuance intention," Electronic Commerce Research and Applications, vol. 14, no. 6, pp. 418-430, 2015.

[3] S. A. Nikou and A. A. Economides, "Mobile-based assessment: integrating acceptance and motivational factors into a combined model of self-determination theory and technology acceptance," Computers in Human Behavior, vol. 68, pp. 83-95, 2017.

[4] F. Abdullah and R. Ward, "Developing a general extended technology acceptance model for E-learning (GETAMEL) by analysing commonly used external factors," Computers in Human Behavior, vol. 56, pp. 238-256, 2016.

[5] C. A. Lin and T. Kim, "Predicting user response to sponsored advertising on social media via the technology acceptance model," Computers in Human Behavior, vol. 64, pp. 710-718, 2016.

[6] J. Joo and Y. Sang, "Exploring Koreans' smartphone usage: an integrated model of the technology acceptance model and uses and gratifications theory," Computers in Human Behavior, vol. 29, no. 6, pp. 2512-2518, 2013.

[7] A. Japutra, Y. Ekinci, and L. Simkin, "Self-congruence, brand attachment and compulsive buying," Journal of Business Research, vol. 25, 2017.

[8] Y. S. Kang, S. Hong, and H. Lee, "Exploring continued online service usage behavior: the roles of self-image congruity and regret," Computers in Human Behavior, vol. 25, no. 1, pp. 111-122, 2009.
[9] M. J. Sirgy, "Self-image/product-image congruity and advertising strategy," in Proceedings of the 1982 Academy of Marketing Science (AMS) Annual Conference, Springer, Berlin, Germany, 2015.

[10] M. J. Sirgy, J. S. Johar, A. C. Samli, and C. B. Claiborne, "Selfcongruity versus functional congruity: predictors of consumer behavior," Journal of the Academy of Marketing Science, vol. 19, no. 4, pp. 363-375, 1991.

[11] T. Islam, "The impact of self-congruity (symbolic and functional) on the brand hate: a study based on self-congruity theory," British Food Journal, vol. 10, 2018.

[12] M. van Dijk, H. Van Herk, and R. Prins, "Choosing your charity: the importance of value congruence in two-stage donation choices," Journal of Business Research, vol. 105, pp. 283-292, 2019.

[13] M. J. Sirgy, J. Johar, and C. Claiborne, "Self-concept motivation as mediator between self-image congruence and attitude/intention," in Proceedings of the 1992 Academy of Marketing Science (AMS) Annual Conference, Springer, Berlin, Germany, 2015.

[14] A. Jamal and M. M. Goode, "Consumers and brands: a study of the impact of self-image congruence on brand preference and satisfaction," Marketing Intelligence \& Planning, vol. 66, 2001.

[15] T. R. Graeff, "Image congruence effects on product evaluations: the role of self-monitoring and public/private consumption," Psychology and Marketing, vol. 13, no. 5, pp. 481-499, 1996.

[16] M. J. Sirgy, "Using self-congruity and ideal congruity to predict purchase motivation," Journal of Business Research, vol. 13, no. 3, pp. 195-206, 1985.

[17] A. Jamal and M. Al-Marri, "Exploring the effect of self-image congruence and brand preference on satisfaction: the role of expertise," Journal of Marketing Management, vol. 23, no. 78, pp. 613-629, 2007.

[18] M. J. Sirgy and C. Su, "Destination image, self-congruity, and travel behavior: toward an integrative model," Journal of Travel Research, vol. 38, no. 4, pp. 340-352, 2000.

[19] T. P. Liang, C. W. Huang, Y. H. Yeh, and B. Lin, "Adoption of mobile technology in business: a fit-viability model," Industrial Management \& Data Systems, vol. 107, no. 8, pp. 1154-1169, 2007.

[20] D. Persico, S. Manca, and F. Pozzi, "Adapting the Technology Acceptance Model to evaluate the innovative potential of e-learning systems," Computers in Human Behavior, vol. 30, pp. 614-622, 2014.

[21] J. K. Ayeh, “Travellers' acceptance of consumer-generated media: an integrated model of technology acceptance and source credibility theories," Computers in Human Behavior, vol. 48, pp. 173-180, 2015.

[22] K.-B. Ooi and G. W.-H. Tan, "Mobile technology acceptance model: an investigation using mobile users to explore smartphone credit card," Expert Systems with Applications, vol. 59, pp. 33-46, 2016.

[23] A. Muk and C. Chung, "Applying the technology acceptance model in a two-country study of SMS advertising," Journal of Business Research, vol. 68, no. 1, pp. 1-6, 2015.

[24] Z. Sheikh, T. Islam, S. Rana, Z. Hameed, and U. Saeed, "Acceptance of social commerce framework in Saudi Arabia," Telematics and Informatics, vol. 34, no. 8, pp. 1693-1708, 2017.

[25] S. Parameswaran, R. Kishore, and P. Li, "Within-study measurement invariance of the UTAUT instrument: an assessment with user technology engagement variables," 
Information \& Management, vol. 52, no. 3, pp. 317-336, 2015.

[26] G. McLean, K. Al-Nabhani, and A. Wilson, "Developing a mobile applications customer experience model (MACE)implications for retailers," Journal of Business Research, vol. 85, pp. 325-336, 2018.

[27] S. Y. Yousafzai, G. R. Foxall, and J. G. Pallister, "Explaining internet banking behavior: theory of reasoned action, theory of planned behavior, or technology acceptance model?" Journal of Applied Social Psychology, vol. 40, no. 5, pp. 1172-1202, 2010.

[28] D. L. Goodhue and R. L. Thompson, "Task-technology fit and individual performance," MIS Quarterly, vol. 19, no. 2, pp. 213-236, 1995.

[29] J. Lee, F. A. Cerreto, and J. Lee, “Theory of planned behavior and teachers' decisions regarding use of educational technology," Journal of Educational Technology \& Society, vol. 13, no. 1, pp. 152-164, 2010.

[30] R. Roy, F. Akhtar, and N. Das, "Entrepreneurial intention among science \& technology students in India: extending the theory of planned behavior," International Entrepreneurship and Management Journal, vol. 13, no. 4, pp. 1013-1041, 2017.

[31] T. H. Baek and C. Y. Yoo, "Branded app usability: conceptualization, measurement, and prediction of consumer loyalty," Journal of Advertising, vol. 47, no. 1, pp. 70-82, 2018.

[32] A. Annie, "The state of mobile 2019," Computers in Human Behavior, 2018.

[33] J.-Y. M. Kang, J. M. Mun, and K. K. P. Johnson, "In-store mobile usage: downloading and usage intention toward mobile location-based retail apps," Computers in Human Behavior, vol. 46, pp. 210-217, 2015.

[34] C.-H. Jin, "Self-concepts in cyber censorship awareness and privacy risk perceptions: what do cyber asylum-seekers have?" Computers in Human Behavior, vol. 80, pp. 379-389, 2018.

[35] T. Wang, "Antecedents of emotional attachment of social media users," The Service Industries Journal, vol. 36, no. 9-10, pp. 438-451, 2016.

[36] J.-J. Hew, "Hall of fame for mobile commerce and its applications: a bibliometric evaluation of a decade and a half (2000-2015)," Telematics and Informatics, vol. 34, no. 1, pp. 43-66, 2017.

[37] W. R. King and J. He, "A meta-analysis of the technology acceptance model," Information \& Management, vol. 43, no. 6, pp. 740-755, 2006.

[38] N. Marangunić and A. Granić, "Technology acceptance model: a literature review from 1986 to 2013," Universal Access in the Information Society, vol. 14, no. 1, pp. 81-95, 2015.

[39] P. Blomkvist, "Bridging the critical interface: ambidextrous innovation for water provision in Nairobi's informal settlements," Technology in Society, vol. 14, 2019.

[40] M. Martínez-Domínguez and J. Mora-Rivera, "Internet adoption and usage patterns in rural Mexico," Technology in Society, vol. 60, p. 101226, 2020.

[41] A. Reyes-Menendez, "Understanding the influence of wireless communications and $\mathrm{Wi}-\mathrm{Fi}$ access on customer loyalty: a behavioral model system," Wireless Communications and Mobile Computing, vol. 6, 2018.

[42] V. Konok, D. Gigler, B. M. Bereczky, and Á. Miklósi, "Humans' attachment to their mobile phones and its relationship with interpersonal attachment style," Computers in Human Behavior, vol. 61, pp. 537-547, 2016.
[43] M. J. Sirgy, "Materialism and quality of life," Social Indicators Research, vol. 43, no. 3, pp. 227-260, 1998.

[44] C. Claiborne and M. J. Sirgy, "Self-image congruence as a model of consumer attitude formation and behavior: a conceptual review and guide for future research," in Proceedings of the 1990 Academy of Marketing Science (AMS) Annual Conference, Springer, Berlin, Germany, 2015.

[45] I. Jacob, M. Khanna, and K. A. Rai, "Attribution analysis of luxury brands: an investigation into consumer-brand congruence through conspicuous consumption," Journal of Business Research, vol. 66, 2019.

[46] T. Ahn, Y. Ekinci, and G. Li, "Self-congruence, functional congruence, and destination choice," Journal of Business Research, vol. 66, no. 6, pp. 719-723, 2013.

[47] J. S. Johar and M. J. Sirgy, "Value-expressive versus utilitarian advertising appeals: when and why to use which appeal," Journal of Advertising, vol. 20, no. 3, pp. 23-33, 1991.

[48] Z. Sheikh, L. Yezheng, T. Islam, Z. Hameed, and I. U. Khan, "Impact of social commerce constructs and social support on social commerce intentions," Information Technology \& People, vol. 32, no. 1, pp. 68-93, 2019.

[49] T. Abimbola, "Self-congruity, brand attitude, and brand loyalty: a study on luxury brands," European Journal of Marketing, vol. 66, 2012.

[50] F. Kressmann, M. J. Sirgy, A. Herrmann, F. Huber, S. Huber, and D.-J. Lee, "Direct and indirect effects of self-image congruence on brand loyalty," Journal of Business Research, vol. 59, no. 9, pp. 955-964, 2006.

[51] S. Hosany and D. Martin, "Self-image congruence in consumer behavior," Journal of Business Research, vol. 65, no. 5, pp. 685-691, 2012.

[52] T. Islam, A. H. Pitafi, V. Arya et al., "Panic buying in the COVID-19 pandemic: a multi-country examination," Journal of Retailing and Consumer Services, vol. 66, 2020.

[53] M. J. Sirgy, "Self-concept in consumer behavior: a critical review," Journal of Consumer Research, vol. 9, no. 3, pp. 287-300, 1982.

[54] Y. Ekinci and M. Riley, "An investigation of self-concept: actual and ideal self-congruence compared in the context of service evaluation," Journal of Retailing and Consumer Services, vol. 10, no. 4, pp. 201-214, 2003.

[55] J. L. Aaker, "The malleable self: the role of self-expression in persuasion," Journal of Marketing Research, vol. 36, no. 1, pp. 45-57, 1999.

[56] A. Usakli and S. Baloglu, "Brand personality of tourist destinations: an application of self-congruity theory," Tourism Management, vol. 32, no. 1, pp. 114-127, 2011.

[57] J. C. Harsanyi, "Acceptance of empirical statements: a Bayesian theory without cognitive utilities," Theory and Decision, vol. 18, no. 1, pp. 1-30, 1985.

[58] A. U. Jan and V. Contreras, "Technology acceptance model for the use of information technology in universities," Computers in Human Behavior, vol. 27, no. 2, pp. 845-851, 2011.

[59] A. Gruzd, K. Staves, and A. Wilk, "Connected scholars: examining the role of social media in research practices of faculty using the UTAUT model," Computers in Human Behavior, vol. 28, no. 6, pp. 2340-2350, 2012.

[60] I. Akman and A. Mishra, "Sector diversity in green information technology practices: technology acceptance model perspective," Computers in Human Behavior, vol. 49, pp. 477-486, 2015.

[61] L. G. Wallace and S. D. Sheetz, "The adoption of software measures: a technology acceptance model (TAM) 
perspective," Information \& Management, vol. 51, no. 2, pp. 249-259, 2014.

[62] V. S. Lai and H. Li, "Technology acceptance model for internet banking: an invariance analysis," Information \& Management, vol. 42, no. 2, pp. 373-386, 2005.

[63] F. D. Davis, "Perceived usefulness, perceived ease of use, and user acceptance of information technology," MIS Quarterly, vol. 13, no. 3, pp. 319-340, 1989.

[64] J. C. Sánchez-Prieto, S. Olmos-Migueláñez, and F. J. GarcíaPeñalvo, "MLearning and pre-service teachers: an assessment of the behavioral intention using an expanded TAM model," Computers in Human Behavior, vol. 72, pp. 644-654, 2017.

[65] C. Moraes, M. Carrigan, C. Bosangit, C. Ferreira, and M. McGrath, "Understanding ethical luxury consumption through practice theories: a study of fine jewellery purchases," Journal of Business Ethics, vol. 145, no. 3, pp. 525-543, 2017.

[66] M. J. Mortenson and R. Vidgen, "A computational literature review of the technology acceptance model," International Journal of Information Management, vol. 36, no. 6, pp. 1248-1259, 2016.

[67] N. Park, M. Rhoads, J. Hou, and K. M. Lee, "Understanding the acceptance of teleconferencing systems among employees: an extension of the technology acceptance model," Computers in Human Behavior, vol. 39, pp. 118-127, 2014.

[68] B. Šumak and A. Šorgo, "The acceptance and use of interactive whiteboards among teachers: differences in UTAUT determinants between pre-and post-adopters," Computers in Human Behavior, vol. 64, pp. 602-620, 2016.

[69] J. Khalilzadeh, A. B. Ozturk, and A. Bilgihan, "Security-related factors in extended UTAUT model for NFC based mobile payment in the restaurant industry," Computers in Human Behavior, vol. 70, pp. 460-474, 2017.

[70] I. Im, S. Hong, and M. S. Kang, "An international comparison of technology adoption," Information \& Management, vol. 48, no. 1, pp. 1-8, 2011.

[71] K. Magsamen-Conrad, S. Upadhyaya, C. Y. Joa, and J. Dowd, "Bridging the divide: using UTAUT to predict multigenerational tablet adoption practices," Computers in Human Behavior, vol. 50, pp. 186-196, 2015.

[72] T. Casey and E. Wilson-Evered, "Predicting uptake of technology innovations in online family dispute resolution services: an application and extension of the UTAUT," Computers in Human Behavior, vol. 28, no. 6, pp. 2034-2045, 2012.

[73] I. M. Macedo, "Predicting the acceptance and use of information and communication technology by older adults: an empirical examination of the revised UTAUT2," Computers in Human Behavior, vol. 75, pp. 935-948, 2017.

[74] S. R. Sumter and L. Vandenbosch, "Dating gone mobile: demographic and personality-based correlates of using smartphone-based dating applications among emerging adults," New Media \& Society, vol. 21, no. 3, pp. 655-673, 2019.

[75] R. Xu, R. M. Frey, E. Fleisch, and A. Ilic, "Understanding the impact of personality traits on mobile app adoption - insights from a large-scale field study," Computers in Human Behavior, vol. 62, pp. 244-256, 2016.

[76] L. Murphy, P. Benckendorff, and G. Moscardo, "Linking travel motivation, tourist self-image and destination brand personality," Journal of Travel \& Tourism Marketing, vol. 22, no. 2, pp. 45-59, 2007.
[77] B. F. Smaradottir, J. A. Håland, and S. G. Martinez, "User evaluation of the smartphone screen reader VoiceOver with visually disabled participants," Mobile Information Systems, vol. 66, 2018.

[78] N. B. Amaral and B. Loken, "Viewing usage of counterfeit luxury goods: social identity and social hierarchy effects on dilution and enhancement of genuine luxury brands," Journal of Consumer Psychology, vol. 26, no. 4, pp. 483-495, 2016.

[79] J. E. Escalas and J. R. Bettman, "You are what they eat: the influence of reference groups on consumers' connections to brands," Journal of Consumer Psychology, vol. 13, no. 3, pp. 339-348, 2003.

[80] G. van Noort and E. A. van Reijmersdal, "Branded apps: explaining effects of brands' mobile phone applications on brand responses," Journal of Interactive Marketing, vol. 45, pp. 16-26, 2019.

[81] A. Floh and M. Madlberger, "The role of atmospheric cues in online impulse-buying behavior," Electronic Commerce Research and Applications, vol. 12, no. 6, pp. 425-439, 2013.

[82] M. J. Sirgy, S. Grzeskowiak, and C. Su, "Explaining housing preference and choice: the role of self-congruity and functional congruity," Journal of Housing and the Built Environment, vol. 20, no. 4, pp. 329-347, 2005.

[83] K. Hung and J. F. Petrick, "The role of self- and functional congruity in cruising intentions," Journal of Travel Research, vol. 50, no. 1, pp. 100-112, 2011.

[84] J. C. Sánchez-Prieto, S. Olmos-Migueláñez, and F. J. GarcíaPeñalvo, "Informal tools in formal contexts: development of a model to assess the acceptance of mobile technologies among teachers," Computers in Human Behavior, vol. 55, pp. 519-528, 2016.

[85] F. Muñoz-Leiva, S. Climent-Climent, and F. Liébana-Cabanillas, "Determinants of intention to use the mobile banking apps: an extension of the classic TAM model," Spanish Journal of Marketing-ESIC, vol. 21, no. 1, pp. 25-38, 2017.

[86] P. R. Palos-Sanchez, J. R. Saura, and F. Debasa, "The influence of social networks on the development of recruitment actions that favor user interface design and conversions in mobile applications powered by linked data," Mobile Information Systems, vol. 2018, 2018.

[87] H. Liu, H. Chu, Q. Huang, and X. Chen, "Enhancing the flow experience of consumers in China through interpersonal interaction in social commerce," Computers in Human Behavior, vol. 58, pp. 306-314, 2016.

[88] I. U. Khan, Z. Hameed, Y. Yu, T. Islam, Z. Sheikh, and S. U. Khan, "Predicting the acceptance of MOOCs in a developing country: application of task-technology fit model, social motivation, and self-determination theory," Telematics and Informatics, vol. 35, no. 4, pp. 964-978, 2018.

[89] T. Islam, Z. Sheikh, Z. Hameed, I. U. Khan, and R. I. Azam, "Social comparison, materialism, and compulsive buying based on stimulus-response-model: a comparative study among adolescents and young adults," Young Consumers, vol. 19, no. 1, pp. 19-37, 2018.

[90] X. Hu, X. Chen, and R. M. Davison, "Social support, source credibility, social influence, and impulsive purchase behavior in social commerce," International Journal of Electronic Commerce, vol. 23, no. 3, pp. 297-327, 2019.

[91] M. J. Sirgy, D. Grewal, T. F. Mangleburg et al., "Assessing the predictive validity of two methods of measuring self-image congruence," Journal of the Academy of Marketing Science, vol. 25, no. 3, p. 229, 1997. 
[92] P. K. Chopdar, N. Korfiatis, V. J. Sivakumar, and M. D. Lytras, "Mobile shopping apps adoption and perceived risks: a cross-country perspective utilizing the Unified Theory of Acceptance and Use of Technology," Computers in Human Behavior, vol. 86, pp. 109-128, 2018.

[93] D. F. Polit and C. T. Beck, "The content validity index: are you sure you know what's being reported? Critique and recommendations," Research in Nursing \& Health, vol. 29, no. 5, pp. 489-497, 2006.

[94] R. W. Brislin, "Translation and content analysis of oral and written materials," Methodology, vol. 66, pp. 389-444, 1980.

[95] T. Von der Heidt and D. Scott, "Rethinking the role of external collaboration in product innovation," International Journal of Entrepreneurship and Innovation Management, vol. 15, no. 1-2, pp. 59-90, 2012.

[96] J. F. Hair, C. M. Ringle, and M. Sarstedt, "PLS-SEM: indeed a silver bullet," Journal of Marketing Theory and Practice, vol. 19, no. 2, pp. 139-152, 2011.

[97] D. Gefen and D. Straub, "A practical guide to factorial validity using PLS-Graph: tutorial and annotated example," Communications of the Association for Information Systems, vol. 16, no. 1, p. 5, 2005.

[98] C. Fornell and D. F. Larcker, Structural Equation Models with Unobservable Variables and Measurement Error: Algebra and Statistics, SAGE Publications Sage CA, Los Angeles, CA, USA, 1981.

[99] R. P. Sundarraj and N. Manochehri, "Application of an extended TAM model for online banking adoption," Information Resources Management Journal, vol. 24, no. 1, pp. 1-13, 2011.

[100] G. McLean, "Examining the determinants and outcomes of mobile app engagement - a longitudinal perspective," Computers in Human Behavior, vol. 84, pp. 392-403, 2018.

[101] I. A. Junglas and C. Spitzmuller, "A research model for studying privacy concerns pertaining to location-based services," in Proceedings of the 38th Annual Hawaii International Conference on System Sciences, IEEE, Berlin, Germany, 2005.

[102] C. Yoon and S. Kim, "Convenience and TAM in a ubiquitous computing environment: the case of wireless LAN," Electronic Commerce Research and Applications, vol. 6, no. 1, pp. 102-112, 2007.

[103] N. Shaw and K. Sergueeva, "The non-monetary benefits of mobile commerce: extending UTAUT2 with perceived value," International Journal of Information Management, vol. 45, pp. 44-55, 2019.

[104] D. V. Parboteeah, J. S. Valacich, and J. D. Wells, "The influence of website characteristics on a consumer's urge to buy impulsively," Information Systems Research, vol. 20, no. 1, pp. 60-78, 2009.

[105] J. Kim and E. Ah Yu, "The holistic brand experience of branded mobile applications affects brand loyalty," Social Behavior and Personality: An International Journal, vol. 44, no. 1, pp. 77-87, 2016.

[106] X. Zhu, "Using self-congruence theory to explain the interaction effects of brand type and celebrity type on consumer attitude formation," Journal of Business Research, vol. 66, 2019.

[107] V. Kumar and J. K. Nayak, "The role of self-congruity and functional congruity in influencing tourists' post visit behaviour," Advances in Hospitality and Tourism Research (AHTR), vol. 2, no. 2, pp. 24-44, 2014. 